\title{
TRIPLE THERAPY IN CHRONIC HEPATITIS C: initial series in a public health program in the South of Brazil
}

\author{
Paulo R L ALMEIDA ${ }^{1}$, Carla Bortolin FONSECA ${ }^{1}$, Vivian W KOCH${ }^{1}$, Amanda M SOUZA' \\ Alberi A FELTRIN ${ }^{1}$ and Cristiane Valle TOV01,2
}

\begin{abstract}
Background - Chronic hepatitis C has great impact on world's health. Current therapy for genotype 1 hepatitis $\mathrm{C}$ virus includes protease inhibitors boceprevir and telaprevir, associated to standard therapy - peginterferon alfa + ribavirin. There are no published data in Brazil on the results of this new therapy, and it is interesting an evaluation of what was accomplished up to this moment. Objectives - To evaluate virologic response to triple therapy, as well as the safety profile and tolerability. Method-This study is a clinical series of patients receiving triple therapy for $\mathrm{C}$ hepatitis in a single center of a Public Health System of South Brasil. Out of the 121 patients that initiated the triple therapy, the first patients that finished the treatment and evaluated the sustained virological response ( 24 weeks after the end of treatment) were included. Results - Twenty four genotype 1 chronic hepatitis C monoinfected patients were included. Nineteen $(79.2 \%)$ patients had been previously treated. Thirteen $(54.2 \%)$ patients were cirrhotic. Nineteen $(79.2 \%)$ patients completed the planned therapy. By the end of the treatment, $14(58.3 \%)$ out of 24 patients had undetectable viral load. Sustained virologic response occurred in $12(50.0 \%)$ out of 24 patients, $07(58.3 \%)$ in telaprevir group and $05(41.7 \%)$ in boceprevir group. Out of 24 patients under triple therapy, $58 \%(n=14)$ presented anemia. Conclusion - In conclusion, despite the small number of patients treated with triple therapy evaluated in the current study, it possibly reflects the population under this therapy in real-life. HEADINGS - Hepatitis C. Protease inhibitors. Chronic C hepatitis, therapy.
\end{abstract}

\section{INTRODUCTION}

More than 170 million people worldwide suffer from chronic infection with the hepatitis $C$ virus $(\mathrm{HCV})^{(10)}$. It is a leading cause of end-stage liver disease and hepatocellular carcinoma worldwide, and the most common indication for orthotopic liver transplantation in the Western world ${ }^{(12)}$.

The current therapy to genotype 1 hepatitis $\mathrm{C}$ involves peginterferon alfa and ribavirin $(\mathrm{PR})$ associated with a protease inhibitor (PI), boceprevir (BOC) or telaprevir (TVR). The triple therapy has shown an increase in the sustained virologic response (SVR), despite the increase of adverse effects ${ }^{(2,5,8,9,14)}$.

The efficacy of triple therapy was assessed in approximately 2,290 patients with chronic hepatitis C genotype 1 who had not been treated previously [ADVANCE ${ }^{(5)}$ and ILLUMINATE ${ }^{(9)}$ ] or who had failed previous treatment with PR - REALIZE ${ }^{(14)}$. According to the register trials, adding TVR to the treatment containing PR has shown significant in- crease in the SVR rates compared to the ones from the double therapy with PR (between $70 \%$ to $80 \%$ in triple therapy versus $30 \%$ in the double therapy).

Triple therapy with BOC was assessed in approximately 1,700 patients who had not been treated before ${ }^{(8)}$ or who had failed the previous treatment with $\mathrm{PR}^{(2)}$. In these studies, adding BOC to the treatment containing PR has significantly increased the rates of SVR compared to the standard therapy (between $60 \%$ to $70 \%$ in triple therapy versus $30 \%$ in standard).

The study PROVIDE(11), a sub-analysis including prior null responders recruited from the studies SPRINT-2 and RESPOND-2, evaluated the response rates in the retreatment with $\mathrm{BOC}$ and $\mathrm{PR}$ in this population. The observed SVR was $38 \%$.

Triple therapy was incorporated in Brazil by the National Committee for the Incorporation of Technologies (CONITEC) ${ }^{(6)}$ in 2012 and treatments initiated in 2013.

This study aimed at evaluating the virologic response and adverse effects associated to the triple

Declared conflict of interest of all authors: none

Disclosure of funding: no funding received

${ }^{1}$ Hospital Nossa Senhora da Conceição - HNSC; ${ }^{2}$ Serviço de Gastro-Hepatologia, Universidade Federal de Ciências da Saúde de Porto Alegre - UFCSPA. Porto Alegre RS, Brasil.

Correspondence: Prof. Cristiane Valle Tovo. Rua Cel. Aurélio Bitencourt, 115, 201. CEP: 90430-080 - Porto Alegre, RS, Brasil. E-mail: cris.tovo@terra.com.br 
therapy in the first patients that were going through this treatment in real life in a tertiary attendance Hospital and reference for liver disease in South Brazil.

\section{METHODS}

A descriptive and retrospective observational study was carried out using information from patient's records attended in in a public center for hepatitis $\mathrm{C}$ attendance in a tertiary Public Hospital in the South of Brazil. It is an assessment of the first patients going through the triple therapy (PR and PI). There were 121 patients monoinfected with genotype 1 hepatitis $\mathrm{C}$ who went through triple therapy against $\mathrm{HCV}$, and the present study analyse the data of the first patients who finished the treatment and evaluated the sustained virological response, defined as undetectable HCV-RNA 24 weeks after the end of the therapy. Data were acquired retrospectively and stored in a database charts.

Information about the sustained virological response, adverse effects and early withdraw and their reasons were assessed $^{(7)}$.

Anemia was graded according to the World Health Organization (WHO) scale: Grade I $(9.5-10.9 \mathrm{~g} / \mathrm{dl})$, Grade II $(8.0-9.4 \mathrm{~g} / \mathrm{dL})$, Grade III $(6.5-7.9 \mathrm{~g} / \mathrm{dL})$ and Grade IV $(<6.5 \mathrm{~g} / \mathrm{dL})^{(13)}$.

\section{RESULTS}

Twenty-four patients monoinfected with genotype 1 hepatitis $\mathrm{C}$ who went through triple therapy with PR and PI were assessed. Twelve patients received BOC and 12 TVR.

Fifteen patients were men $(62.5 \%), 18$ were white $(75.0 \%)$ and the average age was 55.2 years old. The average body mass index (BMI) was $27.9 \mathrm{~kg} / \mathrm{m}^{2}$.

Most of the patients $(14 ; 58.3 \%)$ presented comorbidities (systemic arterial hypertension was the most common). Fifteen $(62.5 \%)$ patients used medication besides the ones that were part of the studied therapy $-09(37.5 \%)$ of them used one or more drugs that could interact with the IP used.

Nineteen $(79.0 \%)$ patients had already gone through previous treatments: $09(47.3 \%)$ were null responders, 06 $(31.6 \%)$ were relapsing and $04(21 \%)$ did not have records of their previous results.

Thirteen (54.2\%) patients had cirrhosis, according to clinic and/or laboratorial information or hepatic biopsy; 05 $(20.8 \%)$ patients had biopsy with Metavir score of fibrosis F3 and $05(20.8 \%)$ patients, fibrosis F2. One of the patients did not have liver biopsy or clinical documentation of cirrhosis.

The average viral load (VL) before the treatment was $4,213,040 \mathrm{UI} / \mathrm{mL}(63,500$ to $26,920,077)$. Most of the patients $(16 ; 66.7 \%)$ showed high VL $(>600,000 \mathrm{UI} / \mathrm{mL})$.

In the week $4,11 / 12(91.7 \%)$ patients using TVR reached undetectable VL, while in the BOC group 8/12 patients evaluated the viral load, but only one (12.5\%) had an undetectable VL.

In the week 12 , most of the patients $(19 ; 79.2 \%)$ had an undetectable VL, with similar numbers in both groups. One patient did not evaluate the VL because of treatment withdraw in the seventh week due to a detectable VL in week 4.

Sixteen $(66.7 \%)$ patients completed the whole planned treatment. Three patients did not complete the treatment but they also reached an undetectable VL. Thereby, 14/24 (58.3\%) patients had undetectable VL at the end of the treatment.

When it was accessed the SVR, the VL was still undetectable in $12(50 \%)$ patients $-07(58.3 \%)$ from the TVR group and $05(41.7 \%)$ in BOC group.

Summing up, the results were the following: $19(79.2 \%)$ patients completed the treatment; $12(50 \%)$ patients presented SVR; among those patients who interrupted the therapy, 04 $(16.7 \%)$ were due to therapeutic failure and $01(4.2 \%)$ because of adverse effects (Figure 1).

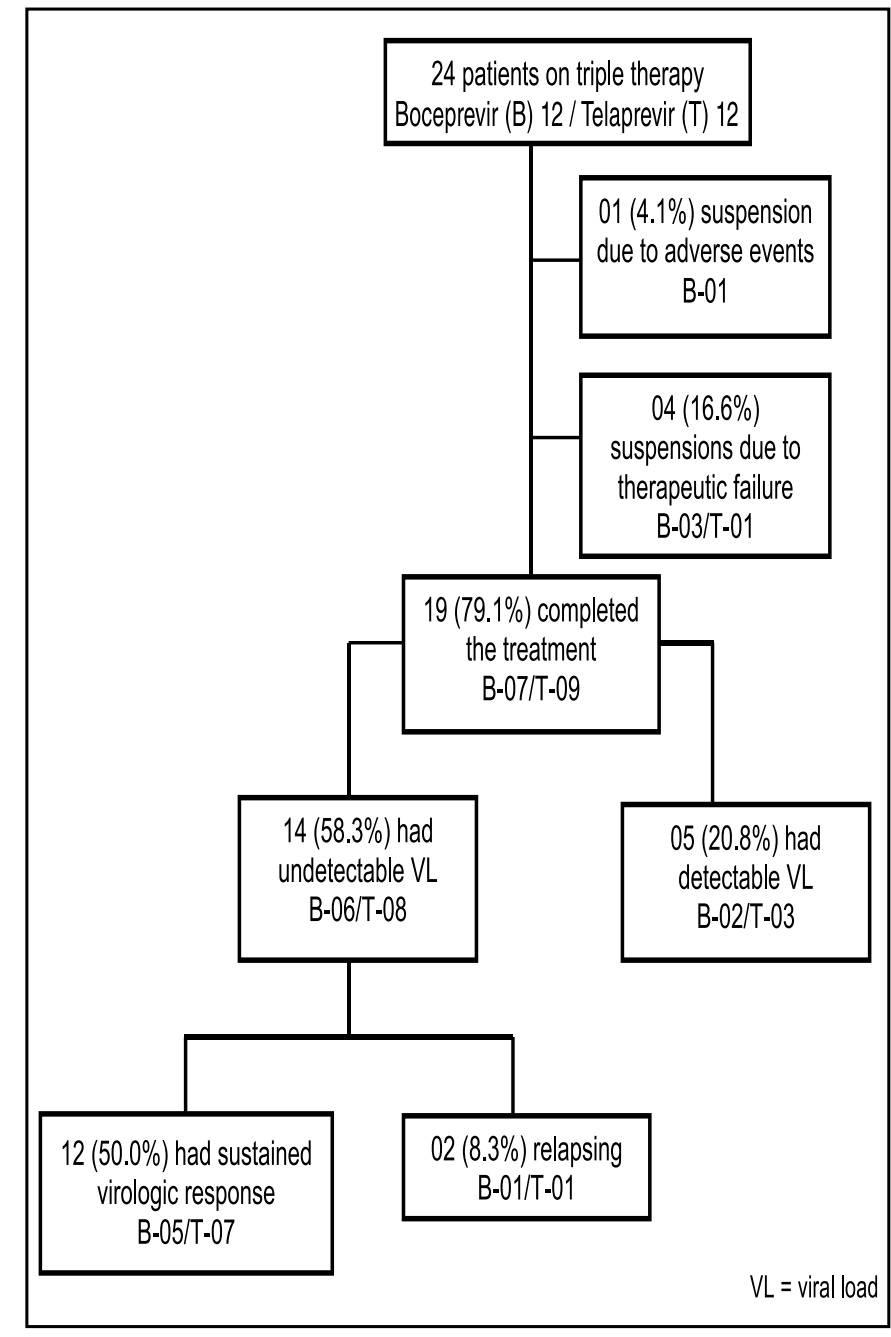

FIGURE 1. Flow diagram of study patients

Regarding adverse effects (AE), 09 (37.5\%) patients presented itching (05 TVR and 04 BOC); $02(8.3 \%)$ patients using TVR presented cutaneous rash; $09(37.5 \%)$ patients presented anorectal symptoms (07 TVR); 02 (8.3\%) referred dysgeusia. 
One patient in the BOC interrupted the treatment due to exacerbation of cardiac failure. Other three patients (one in BOC group and two in TVR group) also presented adverse events that led to withdraw the treatment; however, because they had already presented undetectable VL, their treatments were considered completed by the response guided therapy. Among these patients, one presented thrombocytopenia (BOC), one had anal abscess and thrombocytopenia (TVR) and another patient had asthenia and incapacitating myalgia (TVR).

Fifty-eight percent of the 24 patients who went through triple therapy presented anemia. Among these, five patients presented grade I, six patients presented grade II and three others presented grade III. The BOC group presented anemia in $75 \%$ of the cases while the TVR group presented $41 \%$.

Neutropenia with neutrophil count at 500 to $750 / \mathrm{mm}^{3}$ was evident in $50 \%$ of the patients using BOC and $16 \%$ of the patients using TVR during therapy. There were two cases of severe neutropenia $\left(<500 / \mathrm{mm}^{3}\right)$ - both patients belonged to the BOC group.

Eight patients had severe thrombocytopenia (platelets rate: 20,000 to $50,000 / \mathrm{mm}^{3}$ ); only one patients belonged to the BOC group while the other seven were in the TVR group.

\section{DISCUSSION}

This study presents the experience of the patients treated at a Public Health System center, and to our knowledge, this is the first publication referring to the Brazilian experience with the triple therapy.

In the present case series, the SVR rate of the patients who had gone through triple therapy was $50 \%$ (12 out of 24 patients). The result was lower than previous results that had been published in the trials of register, such as ADVANCE $^{(5)}$, ILLUMINATE ${ }^{(9)}$, REALIZE $^{(14)}$, SPRINT-2( $^{(8)}$ and RESPOND-2(2). The fact that the response was not so exuberant may suggest that these trials do not reflect the health care reality presenting selection biases. Because of the strict criteria for inclusion these patients distance themselves from other patients with common comorbidities who will go under triple therapy in real life. A previously published study in a setting of real-life had already shown lower results with double therapy than the ones described in the original trials ${ }^{(1)}$.

A French study including cirrhotic patients previously experienced and now treated with triple therapy shows SVR rates varying from $19.4 \%$ (null responders) to $74.2 \%$ (relapsers) with TVR and from zero (null responder) to $53.9 \%$ (relapsers) with BOC, which is quite similar to the results found in the present study ${ }^{(4)}$.

Half of all the patients involved in the present case series $(12 / 24)$ presented rapid virologic response (RVR). Most of the patients who reached RVR were in the TVR group $(11 / 12)$ once the patients in the BOC group were still in the lead-in phase.

The complete early virologic response (EVR) was distributed in a more homogenous way - $10(83.3 \%)$ out of 12 patients using TVR and $09(75.0 \%)$ out of 12 using BOC.
Among those patients who used TVR, SVR was observed in all naïve patients. In the ADVANCE ${ }^{(5)}$ study, the SVR, in an intention-to-treat analysis, reached $75 \%$. Among the patients who were previously treated with double therapy, $40 \%$ $(4 / 10)$ presented SVR after the use of TVR. The REALIZE ${ }^{(14)}$ study assessed patients previously treated, and presented a SVR of $80 \%$ in previous relapsing patients, although the response was lower regarding null responders (33\%).

Boceprevir was indicated to 12 patients and 10 of these were previously experienced. SVR was observed in $41.7 \%$ $(5 / 12)$ of the patients -01 naïve and 04 previously treated. In the RESPOND-2(2) study, a SVR of $66 \%$ was obtained with the use of BOC to retreatment. Two patients using BOC were naïve, and only one presented SVR. The SPRINT-2 ${ }^{(11)}$ study, while submitting naïve patients to BOC presented response of $66 \%$.

These studies show that adverse events have been more constant in patients treated with PI than the ones who were treated only with PR. The main adverse events associated with the use of BOC are anemia and dysgeusia ${ }^{(8,11)}$. The average frequency of serious AE was only $12 \%$ among those who received BOC and 5\% in those who received only PR. Concerning TVR, it was noticeable that cutaneous eruptions and itching were more frequent. Besides, adverse effects such as anemia, neutropenia and leukopenia occurred more frequently in the groups of TVR if compared to the control groups $^{(5,9,14)}$.

Although so far a small number of patients were included, the effects are consonant with such trials. Fifty-eighty percent of the patients presented anemia - among the patients using BOC this adverse effect was presented in $75 \%$ of the cases, while in the group of TVR, only in $41 \%$ of the patients.

In the group of patients with cirrhosis, $66 \%$ presented anemia, while among the patients who did not have cirrhosis, only $50 \%$ presented anemia. In the studies of phase III REALIZE $^{(14)}$ and RESPOND-2(2), as well as in the CUPIC ${ }^{(4)}$, the rates of anemia were clearly higher in cirrhotic patients.

Dermatological lesions occurred up to $50 \%$ of the patients, including rash and itching, most prevalently in the group using TVR. According to some already published data, $50 \%$ of the patients treated with TVR presented some dermatological lesion comparing to $32 \%$ of patients who used $\mathrm{BOC}^{(3,4)}$.

In conclusion, although the obtained data refers to a small number of cases, it possibly reflects the reality of clinical practical to be observed during triple therapy in chronic hepatitis $\mathrm{C}$ patients.

\section{Author contributions}

Almeida PRL conceptualized this observational study. Fonseca CB, Koch VW, Souza AM, Feltrin AA and Barros IC performed the data collection; Fonseca CB, Koch VW, Souza AM, Almeida PRL, Mattos AA and Tovo CV wrote the manuscript. Almeida PRL, Mattos AA and Tovo CV also reviewed the manuscript critically for important intellectual content. All authors approved the final version of the manuscript. 
Almeida PRL, Fonseca CB, Koch VW, Souza AM, Feltrin AA, Tovo CV. Terapia tripla em pacientes com hepatite C: experiência inicial em um pólo de aplicação do Sul do Brasil. Arq Gastroenterol. 2015,52(1): 14-7.

RESUMO - Contexto - A hepatite crônica pelo vírus C tem grande impacto na saúde mundial. A terapia atual do genótipo 1 inclui os inibidores de protease (IP) boceprevir e telaprevir, associados à terapia padrão - alfapeginterferona + ribavirina (PR). No Brasil ainda não há estudos publicados sobre os resultados dessa nova terapia, sendo de interesse uma avaliação do que foi realizado até o momento. Objetivos - Avaliar a resposta virológica ao tratamento triplo, bem como o perfil de segurança e tolerabilidade. Métodos - O estudo consta de série de casos dos pacientes em uso de terapia tripla para o tratamento da hepatite C em um polo de tratamento da Secretaria Estadual da Saúde do Estado do Rio Grande do Sul, Brasil. Dentre os 121 pacientes que estão em uso de terapia tripla (PR e IP) foram apresentados os dados referentes aos primeiros que finalizaram o tratamento e realizaram avaliação da resposta virológica sustentada na semana 24 pós-tratamento. Resultados - Foram incluídos 24 pacientes monoinfectados por hepatite C crônica genótipo 1. Dezenove (79\%) pacientes eram previamente experimentados. Treze (54,2\%) pacientes apresentavam cirrose. Dezenove $(79,2 \%)$ pacientes completaram o tratamento planejado. Ao final do tratamento, 14 (58,3\%) dos 24 pacientes apresentaram carga viral indetectável. Resposta virológica sustentada ocorreu em $12(50 \%)$ dos 24 pacientes, sendo $07(58,3 \%)$ no grupo telaprevir e $05(41,7 \%)$ no grupo boceprevir. Dos 24 pacientes submetidos à terapia tripla, $58 \%(\mathrm{n}=14)$ apresentaram anemia. Conclusão - Embora o presente estudo tenha avaliado um pequeno número de casos, possivelmente reflete a população submetida à terapia tripla na vida real, despida das restrições dos estudos de registro.

DESCRITORES - Hepatite C. Inibidores de protease. Hepatite C crônica, terapia.

\section{REFERENCES}

1. Almeida PRL, Mattos AA, Amaral KM, Feltrin AA, Zamin P, Tovo CV, et al Treatment of hepatitis $\mathrm{C}$ with Peginterferon and Ribavirin in a public health program. Hepatogastroenterology. 2009;56(89):223-6.

2. Bacon BR, Gordon SC, Lawitz E, Marcellin P, Vierling JM, Zeuzem S, et al. Boceprevir for previously treated chronic HVL genotype 1 infection. (RESPOND-2). N Engl J Med 2011;364(13):1207-17.

3. Barritt AS, Fried MW. Maximizing Opportunities and Avoiding Mistakes in Triple Therapy for Hepatitis C Virus. Gastroenterology. 2012;142(6):1314-23.

4. Hezode C, Fontaine H, Dorival C, Zoulim F, Larrey D, Canva V, et al. CUPIC Study Group. Effectiveness of telaprevir or boceprevir in treatment-experienced patients with $\mathrm{HCV}$ genotype 1 infection and cirrhosis. Gastroenterology. 2014;pii:S0016-5085(14)00449-1.

5. Jacobson IM, McHutchison JG, Dusheiko G, Di Bisceglie AM, Reddy KR, Bzowej NH, et al. Telaprevir for previously untreated chronic hepatits $\mathrm{C}$ vírus infection. (ADVANCE). New England Journal of Medicine. 2011;364(25):2405-16.

6. Ministério da Saúde. (Brasil). Inibidores de Protease (Boceprevir e Telaprevir) para o tratamento da Hepatite Crônica C. Relatório de Recomendação da Comissão Nacional de Incorporação de Tecnologias no SUS - CONITEC - 01. 2012. [update 2014 May 20]. Available from: http://portal.saude.gov.br/portal/ arquivos/pdf/Rel_IP_Hepatite_C_final.pdf

7. Ministério da Saúde. (Brasil). Protocolo clínico e diretrizes terapêuticas para hepatite viral $\mathrm{C}$ e coinfecções. Manejo do paciente infectado cronicamente pelo genótipo 1 do HCV e fibrose avançada. [update 2014 May 20]. Available from: http://funed.mg.gov.br/wp-content/uploads/2011/07/suplemento_1_protocolo_hep_c.pdf
8. Poordad F, McCone J Jr, Bacon BR, Bruno S, Manns MP, Sulkowski MS, et al (SPRINT-2 Investigators). Boceprevir for untreated chronic HCV genotype 1 infection. New Engl J Med. 2011:364(13):1195-206.

9. Sherman KE, Flamm SL, Afdhal NH, Nelson DR, Sulkowski MS, Everson GT, et al. Response-guided telaprevir combination treatment for hepatitis $\mathrm{C}$ virus infection. (ILLUMINATE). New England Journal of Medicine. 2011;365(11):1014-24.

10. Strader DB, Wright T, Thomas DL, Seeff LB. American Association for the Study of Liver Diseases. Diagnosis, management, and treatment of hepatitis C. Hepatology. 2004;39(4):1147-71.

11. Vierling J, Flamm S, Gordon S, Lawitz E, Bronowicki JP, Davis M, et al. Efficacy of Boceprevir in Prior Null Responders to Peginterferon/Ribavirin: The PROVIDE Study. 62nd Annual Meeting of the American Association for the Study of Liver Diseases, November, 2011, San Francisco, California.

12. Wise M, Bialek S, Finelli L, Bell BP, Sorvillo F. Changing trends in hepatitis C related mortality in the United States, 1995-2004. Hepatology. 2008;47(4):1128-35.

13. World Health Organization (1994) Indicators and Strategies for Iron Deficiency and Anemia Programmes. Report of the WHO/UNICEF/UNU Consultation. Geneva, Switzerland, 6-10 December, 1993

14. Zeuzem S, Andreone P, Pol S, Lawitz E, Diago M, Roberts S, et al. Telaprevir for retreatment of HVL infection (REALIZE). New Engl J Med. 2011;364(25):2417-28.

Received 22/6/2014 Accepted 19/8/2014 